\title{
Torsion of wandering spleen nine years after gastric volvulus: Effect of multiparity?
}

\author{
(D) Serkan Karaisli, M.D., (1) Turan Acar, M.D., 다 Nihan Acar, M.D., \\ (1) Erdinç Kamer, M.D., 달 Mehmet Hacıyanlı, M.D.
}

Department of General Surgery, İzmir Katip Çelebi University Atatürk Training and Research Hospital, İzmir-Turkey

\begin{abstract}
Wandering spleen is a rare condition and has life-threatening complications, such as torsion or infarction. It may be asymptomatic or may present with chronic abdominal pain or intraabdominal mass. Since clinical diagnosis is usually difficult, radiological examinations play a very important role in diagnosis. A 37-year-old multiparous woman was admitted to the emergency room with a complaint of abdominal pain. The patient stated that she underwent an operation due to gastric volvulus nine years ago. Preoperative diagnosis was made by ultrasonography and computed tomography. Splenectomy was performed because of the irreversible infarction. Wandering spleen torsion is a rare clinical condition that may cause an acute abdomen. Computerized tomography is the gold standard for preoperative diagnosis. Gastric volvulus and wandering spleen have similar etiologies. In the literature, the coexistence of these two diseases in adulthood is rarely reported. However, to our knowledge, this case is the first report to describe the emergence of these two pathologies at different times in adulthood.
\end{abstract}

Keywords: Acute abdomen; gastric volvulus; pregnancy; splenectomy; wandering spleen.

\section{INTRODUCTION}

A wandering spleen is a rare entity, which the spleen is in an unusual position and attached only by its hypermobile vascular pedicle. It mostly develops as a result of the ligamentous laxity or lack of ligaments. It may be asymptomatic; it may also present as a painless abdominal mass, frequent recurrent abdominal pain, pressure-related ileus or torsion-related acute abdomen. The spleen is not located in normal anatomic location, and pelvis is the most common localization. ${ }^{[1]}$ When asymptomatic, there is no need for treatment. Laparoscopic or open splenectomy is recommended in the presence of infarction, while splenopexy is adequate in the absence of ischemia. Herein, we aim to present a case that underwent splenectomy due to torted wandering spleen nine years after gastropexy for gastric volvulus.

\section{CASE REPORT}

A 37-year-old Caucasian female patient (Gravidity 4, Parity 4) was admitted to the emergency room with a complaint of abdominal pain, which had lasted for three days. Her past medical history was unremarkable except for detorsion and anterior abdominal wall fixation procedure due to gastric volvulus nine years ago (Gravidity I, Parity I). There was a midline incision scar in the upper abdomen. Physical examination revealed tachycardia, hypotension and axillary body temperature of $38.3{ }^{\circ} \mathrm{C}$. There were severe abdominal tenderness, muscular defense, and a mass was palpated on the suprapubic region. Blood tests were normal except for thrombocytopenia $\left(83.000 / \mathrm{mm}^{3}\right)$, elevated white blood cell count (19200/ $\mathrm{mm}^{3}$ ) and C-reactive protein $(17 \mathrm{mg} / \mathrm{dL})$. Abdominal ultrasonography (US) revealed an enlarged spleen located in the

Cite this article as: Karaisli S, Acar T, Acar N, Kamer E, Hacıyanlı M. Torsion of wandering spleen nine years after gastric volvulus: Effect of multiparity? Ulus Travma Acil Cerrahi Derg 2020;26:489-492.

Address for correspondence: Serkan Karaisli, M.D.

İzmir Katip Çelebi Üniversitesi Atatürk Eğitim ve Araştırma Hastanesi, Genel Cerrahi Kliniği, İzmir, Turkey

Tel: +90 232 - 2434343 E-mail: skaraisli@hotmail.com 

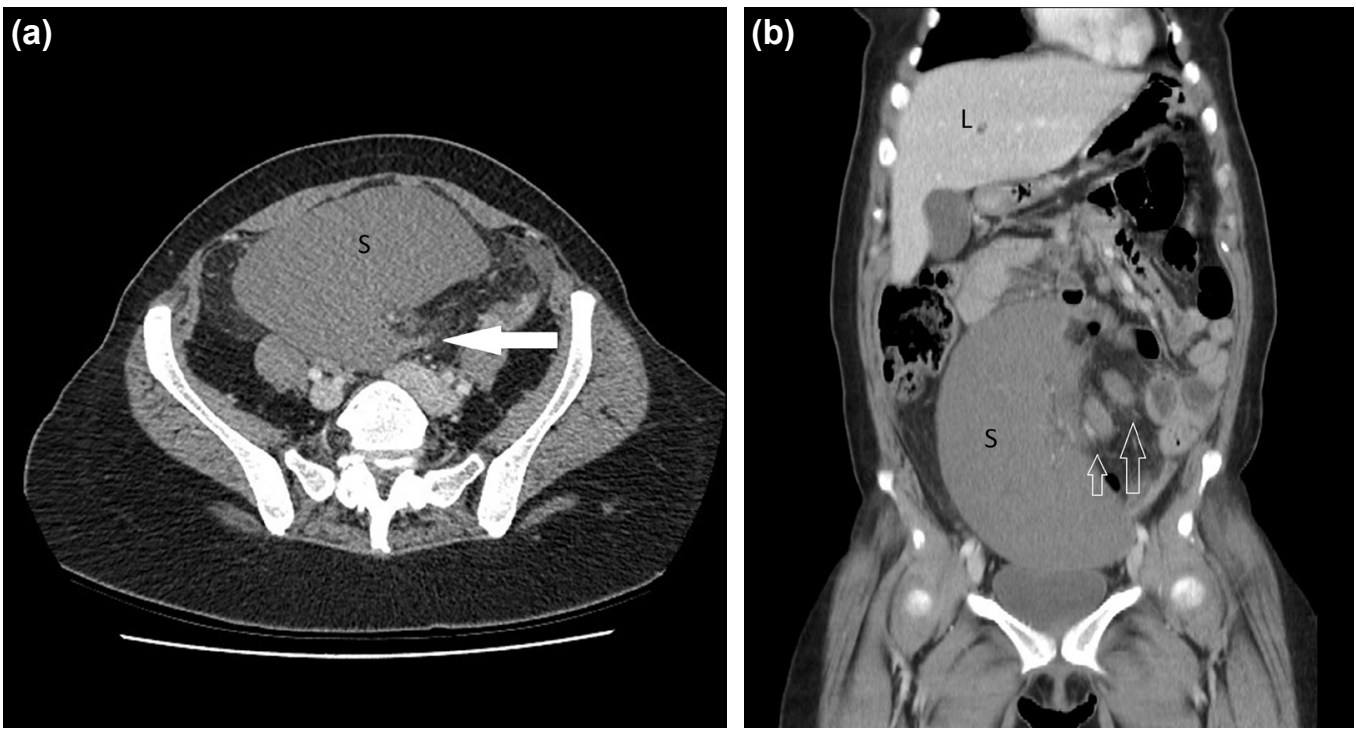

Figure 1. Axial image of computed tomography. Pelvic huge spleen (S) and torsion of splenic artery and vein (arrow) are seen (a). Torsion of vessels is clearly seen in two regions on the coronal image of computed tomography (arrows). Pelvic spleen (S) has demonstrably lower intravenous contrast enhancement than liver (L) (b).

pelvis. Contrast-enhanced abdominal computed tomography (CT) showed a giant ischemic pelvic spleen due to vascular torsion (Fig. la, b).

The patient was brought to the operating room and placed in a supine position. A midline incision was applied under general anesthesia. In the intraoperative examination, fixation sutures of the previous operation were seen between the stomach and anterior abdominal wall. A huge pelvic spleen with a long splenic pedicle that was twisted two times $(720$ degrees) was observed. The spleen was ischemic, and multi-

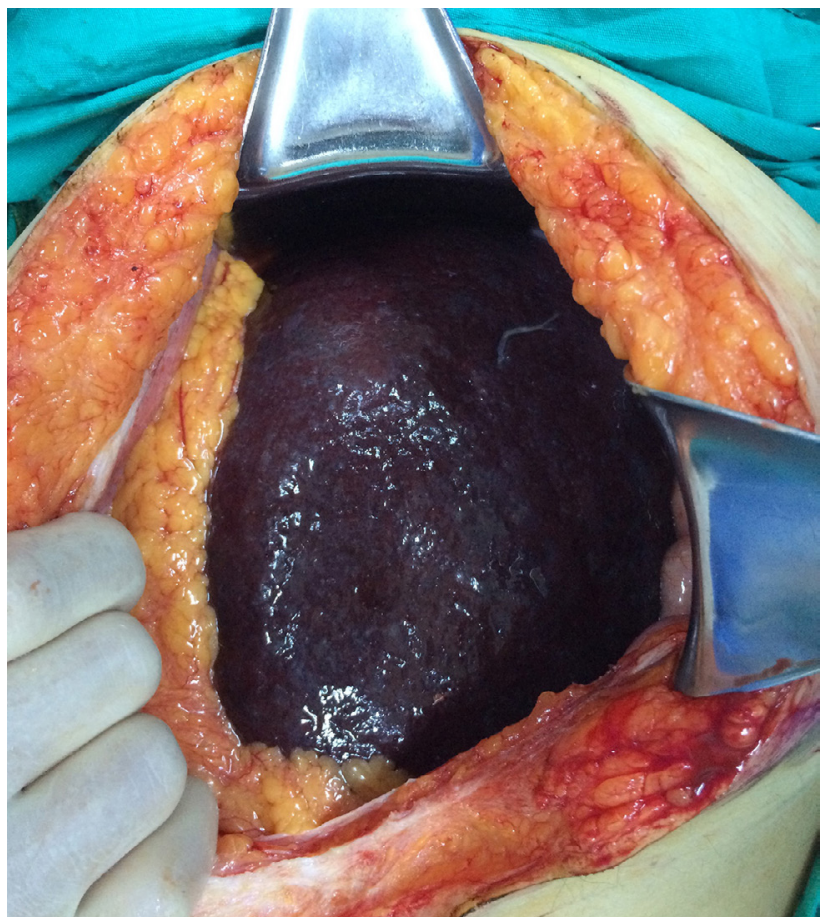

Figure 2. Intraoperative examination of the ischemic spleen. ple foci of necrosis were seen (Fig. 2). Splenectomy was performed because ischemia did not improve when the spleen was detorsioned. A drain was placed to the Douglas pouch.

The patient was discharged on the fourth postoperative day without any complication. Postoperative pneumococcal, meningococcal and influenza vaccines were administered two weeks after the operation. The pathological examination confirmed a congestive ischemic spleen. The patient had remained well for a two-year follow-up period. Written informed consent was obtained from the patient who participated in this study.

\section{DISCUSSION}

Wandering spleen is not a common condition and accounts for less than $0.5 \%$ of all splenectomies. Approximately 500 cases have been described in the literature. Children under 10 years old accounts for a third of all cases. $70-80 \%$ of adult patients are women and the risk increases in the age group of $20-40$ years. ${ }^{[1]}$ The spleen is fixed in its anatomical position by the gastrosplenic, splenocolic and splenorenal ligaments. The wandering spleen usually migrates into the pelvis due to the effect of gravity. The wandering spleen may occur due to congenital malformations of the ligaments or long splenic pedicle. Some diseases, such as malaria, lymphoma and chronic myeloid leukemia, which cause splenomegaly, are considered as acquired causes. Abdominal wall weakness, hormonal changes in pregnancy and multiple pregnancies are also associated with wandering spleen, which explains both higher incidences among women in childbearing period and hormonal changes during pregnancy leading to ligamentous laxity. ${ }^{\left[{ }^{[2]}\right.}$

The patients with wandering spleen may be asymptomatic unless splenic torsion occurs. On physical examination, a mobile 
abdominal mass with notched surfaces may be palpated, but a clinical diagnosis is usually difficult. It may also be noticed incidentally on radiological scans applied for a different reason. It may present with chronic abdominal pain due to intermittent spontaneous torsion and detorsion attacks. In a patient with torsion, signs of peritoneal irritation, such as severe abdominal pain, fever, nausea, vomiting, may occur. ${ }^{[2]}$ Additionally, obstructive uropathy, gastric/duodenal/ colonic obstruction and portal hypertension due to the pressure to the adjacent organs may develop. Almost the whole described wandering spleen cases in the literature underwent surgery due to they presented with an acute abdomen. We did not see any reports about long-term follow-up results of asymptomatic patients or who applied conservative surgery. That is why we believe that this rare entity is not considered to be important for clinicians until patients need urgent surgery.

Laboratory findings are nonspecific. Thrombocytopenia and leukocytosis can be detected, such as in our case. The diagnosis is confirmed by radiological examination. Grayscale and Doppler US are effective, cheap, easy and noninvasive methods to detect wandering spleen and torsion. Additionally, Doppler US shows the presence or absence of splenic vascular flow. CT is gold standard for diagnosis. CT shows a whorled appearance, which is a pathognomonic sign of torsion of the splenic pedicle. ${ }^{[3]}$ The enlarged spleen due to venous blockage may be seen. Minimal or absent contrast enhancement of the spleen, which is considered to be an indicator of infarction, may be detected..$^{[3,4]}$ On non-contrast sections, the spleen shows lower density values in comparison with the hepatic parenchyma and hyperdensity of the splenic pedicle may be a sign of the thrombosed vein. ${ }^{[3]} \mathrm{MRI}$ can be preferred as an alternative to CT. Our patient had typical US and CT findings of wandering spleen with complete infarction. The preoperative findings were verified during the intraoperative examination and following pathological examination.

The treatment is surgery. Laparoscopic or open interventions may be performed. The type of surgical procedure is chosen according to the viability of the spleen. If torsion is absent or blood circulation of the detorsioned spleen is normal, splenopexy is recommended. However, if the spleen is ischemic due to thrombosis of splenic artery or vein, splenectomy should be performed. ${ }^{[2]}$. Since our patient had an ischemic spleen, we performed splenectomy.

Gastric volvulus is another rare entity and shares a common etiology with wandering spleen. The coexistence of these two diseases has been described only four times in adults. [5-8] Those cases were reported to have both pathologies at the time of diagnosis. Omata et al. ${ }^{[5]}$ and Lianos et al..$^{[7]}$ made a diagnosis of wandering spleen during surgical intervention, while other authors ${ }^{[6,8]}$ detected it on CT scan preoperatively applied. All authors ${ }^{[5-7]}$ except for one ${ }^{[8]}$ performed gastropexy without splenopexy or splenectomy. Splenic torsion to be constrained splenectomy was not noted in those case reports, and the authors advocated gastric fixation would prevent splenic hypermobility. Authors reported that no relapse or complication was experienced in patients who underwent only gastropexy during a mean of I3-month follow-up. ${ }^{[5,7]}$

In the presented case, there were nine years between the occurrences of these two diseases. No evidence was found about wandering spleen or hiatal hernia when a detailed previous operation note was checked. It was understood that the wandering spleen developed in the later years after the gastropexy procedure. It was learned that gastropexy was administrated to our patient, such as reported cases. Although authors ${ }^{[5,7]}$ presented that no relapse or complication was experienced during their short time follow-up, wandering spleen occurred nine years after gastropexy in our case. That is why long term follow-up should be considered in patients who underwent gastropexy. Additionally, this report is important to show that gastropexy without splenopexy is not adequate to block hypermobility of spleen contrary to what is believed. On the other hand, the patient had a medical history of single pregnancy at the time of the first operation. Torted wandering spleen was observed after three pregnancies, which in nine years. When considered from this point of view, it appears that these pathologies which have a common etiology may not always coexist. We believe that pregnancy and birth processes may increase the risk of wandering spleen in patients with a history of gastric volvulus.

The wandering spleen should be kept in mind in the differential diagnosis of the abdominal mass. Torsion of the pedicle may cause an acute abdomen. In the presence of infarction, open or laparoscopic splenectomy should be planned. Patients with a history of gastric volvulus should be evaluated carefully for wandering spleen, which is another possible result of ligamentous laxity. In addition, we think that being multipara may increase the risk of wandering spleen years after gastropexy operation. Surgeons should be aware of this potential risk for women patients in reproductive age, and long-term follow-up should be considered.

\section{Acknowledgements}

We thank all general surgery department staff for their cooperation. This case report was not supported by any company. None of the authors has financial or proprietary interests in any material mentioned.

Informed Consent: Written informed consent was obtained from the patient for the publication of the case report and the accompanying images.

Peer-review: Internally peer-reviewed.

Authorship Contributions: Concept: T.A., N.A.; Design: S.K., T.A.; Supervision: E.K., M.H.; Fundings: N.A., E.K.; Materials: S.K., T.A.; Data: T.A., E.K.; Analysis: S.K., N.A., M.H.; Literature search: S.K., T.A.; Writing: S.K., N.A.; Critical revision: E.K., M.H. 
Conflict of Interest: None declared.

Financial Disclosure: The authors declared that this study has received no financial support.

\section{REFERENCES}

1. Buehner M, Baker MS. The wandering spleen. Surg Gynecol Obstet 1992;175:373-87.

2. Yakan S, Telciler KE, Denecli AG. Acute torsion of a wandering spleen causing acute abdomen. Hong Kong J Emerg Med 2011;18:34-6. [CrossRef]

3. Chu J, Li Z, Luo B, Yang J. Wandering spleen with torsion and complete infarction. Acta Radiol 2011;52:911-3. [CrossRef]

4. Ghahremani S, Sabour M, Ghahremani S, Bazrafshan A, Sadeghi R. A wandering spleen detected by $99 \mathrm{mTc}$-denatured RBC scan. Iran J Nucl
Med 2018;26:66-7.

5. Omata J, Utsunomiya K, Kajiwara Y, Takahata R, Miyasaka N, Sugasawa $\mathrm{H}$, et al. Acute gastric volvulus associated with wandering spleen in an adult treated laparoscopically after endoscopic reduction: a case report. Surg Case Rep 2016;2:47. [CrossRef]

6. Matsushima K, Kayo M, Hachiman H, Gushimiyagi M. Laparoscopic repair of gastric volvulus associated with wandering spleen in an adult: report of a case. Surg Today 2006;36:843-5. [CrossRef]

7. Lianos G, Vlachos K, Papakonstantinou N, Katsios C, Baltogiannis G, Godevenos D. Gastric volvulus and wandering spleen: a rare surgical emergency. Case Rep Surg 2013;2013:561752 [CrossRef]

8. Ooka M, Kohda E, Iizuka Y, Nagamoto M, Ishii T, Saida Y, et al. Wandering spleen with gastric volvulus and intestinal non-rotation in an adult male patient. Acta Radiol Short Rep 2013;2:2047981613499755. [CrossRef]

\section{OLGU SUNUMU - ÖZET}

\section{Gastrik volvulustan dokuz yıl sonra görülen gezici dalak torsiyonu:} Multiparitenin etkisi?

\section{Dr. Serkan Karaisli, Dr. Turan Acar, Dr. Nihan Acar, Dr. Erdinç Kamer, Dr. Mehmet Hacıyanlı}

İzmir Katip Çelebi Üniversitesi Atatürk Eğitim ve Araştırma Hastanesi, Genel Cerrahi Anabilim Dalı, İzmir

Gezici dalak nadir görülen bir durumdur ve torsiyon veya enfarktüs gibi hayatı tehdit eden komplikasyonlara sebep olabilir. Semptomsuz olabilir, kronik abdominal ağrı veya intraabdominal kitle ile prezente olabilir. Klinik tanısı genellikle zor olduğu için, radyolojik incelemeler tanıda çok önemli bir rol oynamaktadır. Otuz yedi yaşında multipar kadın karın ağrısı şikayeti ile acil servise başvurdu. Hastanın öyküsünden dokuz yıl önce gastrik volvulus nedeniyle ameliyat geçirdiğini öğrenildi. Ameliyat öncesi tanı ultrasonografi ve bilgisayarlı tomografi ile yapıldı. İrreversibl infarkt nedeniyle splenektomi yapıldı. Gezici dalak torsiyonu, akut karına neden olabilen nadir bir klinik durumdur. Bilgisayarlı tomografi ameliyat öncesi tanı için altın standarttır. Gastrik volvulus ve gezici dalak benzer etiyolojilere sahiptir. Literatürde, bu iki hastalığın yetişkinlikte birlikteliği nadiren bildirilmiştir. Bununla birlikte, bildiğimiz kadarıyla, bu olgu, yetişkinlikte farklı zamanlarda bu iki patolojinin ortaya çıkışını bildiren ilk çalışmadır.

Anahtar sözcükler: akut karın, gastrik volvulus. gebelik, gezici dalak, splenektomi

Ulus Travma Acil Cerrahi Derg 2020;26(3):489-492 doi: I0.14744/tjtes.2019.91606 